$Q^{2}=$

$23=$ REPORT OF AVACCINATION PROGRAM

(NUR ISTAN)

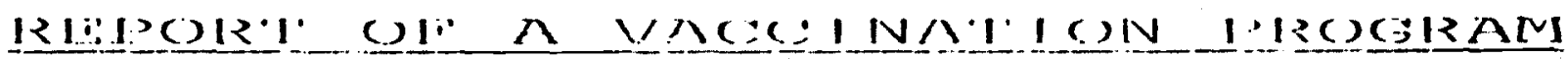

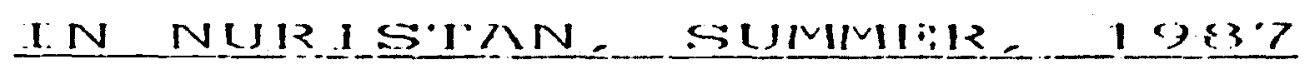

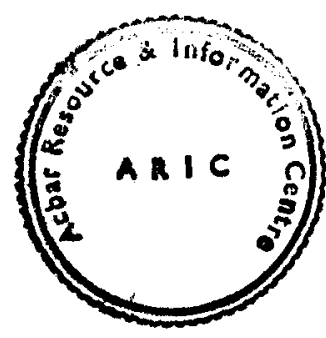

PRETARED BY

KATIIIISN R. CITA. M. D: 


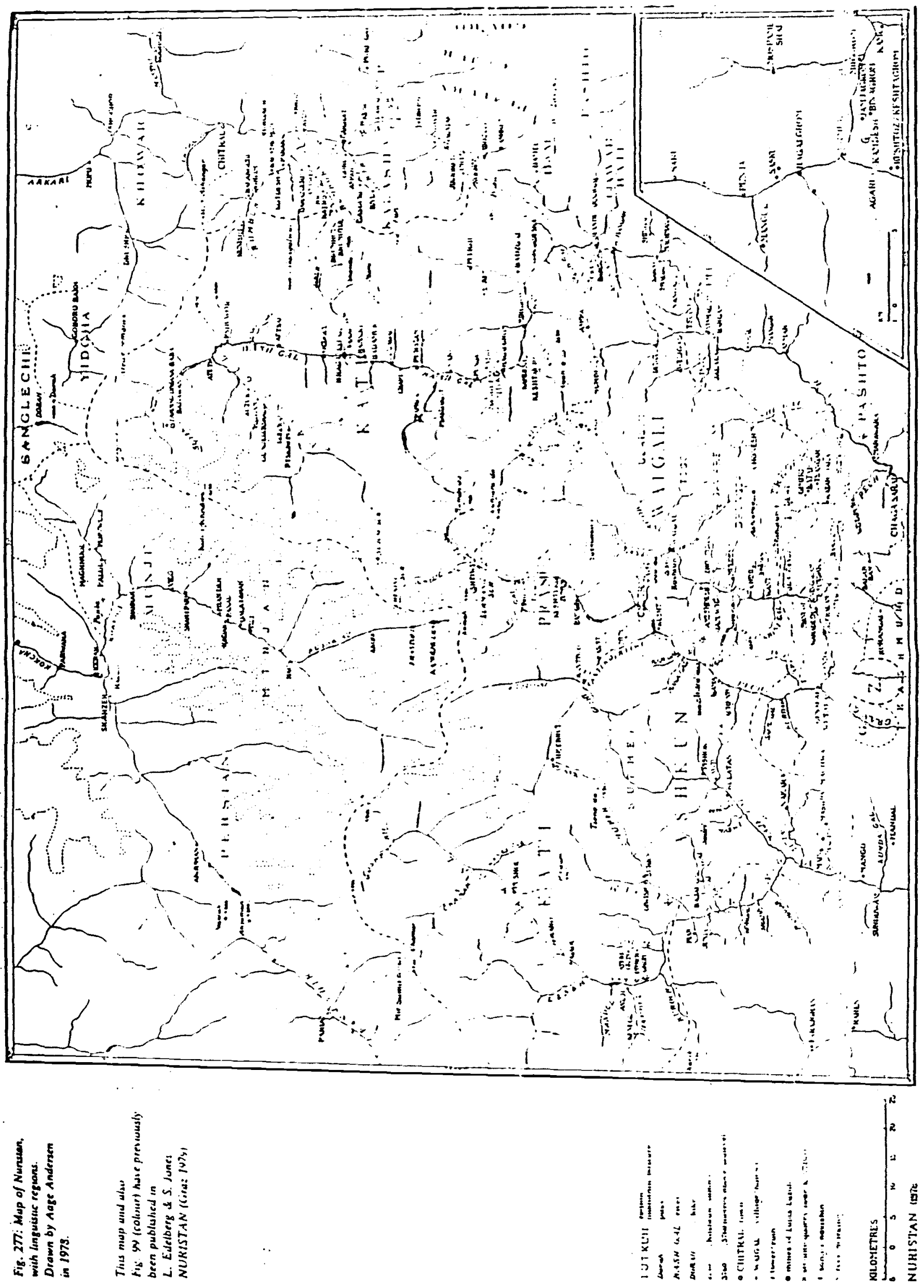


$\Lambda$ toam of three expatriates. ons matso and two doctors. crossed into Nuristan the end of June, $198 \mathrm{i}$. After a four month delay caused by the isealtner and lonistical and political problems, we wore finlly ablo lo gel into n!chanistan. carrying $1500 \mathrm{ka}$. of medicines and supplies ouer a pass of 1600 meters. Nrimals could not. be used due to weather conditions. thus neces: sitoting the use of about 61) porters, who carricd supplies in soveral balchos.

Once in Nuristan, medicel services mexe provided in tiwo separate valleys. The tean frequent ly split up for short periods to extend service to more arcas in the time that was available before the passes closed again in the fall. In all.: approximately 6000 palients weres sen. and 5,300 women and child-

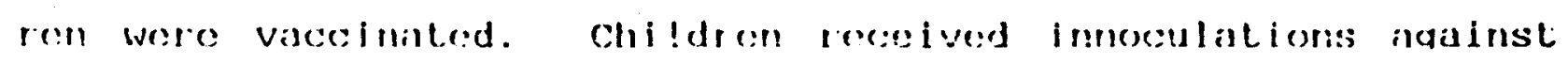
diptheria, pertussis, letanus. Wlic) (combined in a totravalent vaccine-DPPI). measles and I!.C.(.: while all lemales under: age 45 received tetanus vaccine to protect: newbrens against neonatal tetanus.

Gnce inside of Nuristinn we lound that a measless epidemic was just finishing. We did as survey in 11 villages. and found that over 250 kids had dice-about laz of the children under age five. Nuristim has an under five mortality rate of about 10\%. Perhaus a third to a hill of threse deatiss could be prevented by rull vireinilion. Full vaceimation means three separate doses, but in the rase of measles-which kills about as miny kids as all the rest of tho vaccine-provontable discases: combined--a sinale dese conters lifelone proteretion.

The valley just next $l o$ our laraet valley had not been hit with measles, so ve decides to change our program, vaccinating only 1300 persons in the original area twice. and then carrying on into the next valiey where les could use the ineasles vaceine and prevent a similar tracsedy to the one lhat occurred in our target valley while te were stranded in lakistan trying to get inside. 
Population studies done in the ! irst villey indicale that about $90 \%$ of the target population cime for the first set of vaccinations. Bu! tor the 13 villages where two sols of viscoinations

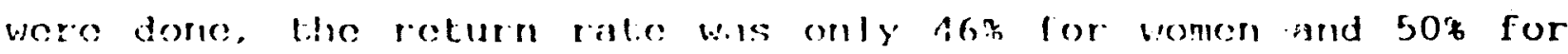
(rhildren.

The text, of this: repert contains il dotailed discussion of the following areas: the reqion and its population, the planned and actual conduct, of the vaceinaticin program, maintanance of the cold chain, communty education and mobilization. proper conduct under the reauircments of purdah, the vaccinator training program, a discussion of problem arcas and suggestions for the fulure, and a statislial rerort.

for a mores detanilond discussion of the medical and logistical aspects of vaccination. see the enclosed Vaccinations in Afghanistan. For a more dotailed description of Nuristan and the incidonces of discoise theres see the onclosed Regional Pepolt: Nuristan. Hhero discrepenciess exist. Lhis final report should bo considered the most aceurate. 


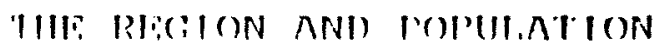

Nuristan is an othnie ragion in norlhern Kunar and Laghman provincess. Hhe indigenous teibes line in lhe nirrow valleys on the southern slopes of the llindu kush. Fhey practised an ancient culturally distinct reliaion with a pantheon of deities until their forced conversion lo 1 : 1 am in 1396. Nuristan was a protected tribal region with restricled acoess to outsiders prior to 1978.

In 1978-79 the local population rose up adainst the government. there were some bombirdmonts at the timo. and rusted tanks can still be seon south of kandesh. There have been no governmont incursions since 1979, and fow bombirdments. With the exception of the Kamdesh area and southern Waiqul, which have reportiedly beon about hall depopulated. most of the rest of Nuristan is intact, with thriving agriculture and busy villages.

The vaceination progrism liss designed to cover the population controlled by an independent, fundamentalist resistance group which calls itself "lhe Islamic Pevolutionary state of Pree Afghanistan". Its leader is a mullah who attended madrasa in lakistan. Nmir Mobimmad Mfral, whe lives in the small village copital of Nik luk (also (alled sinidabad or Bud Muk) in the iniddle of the Bashoul whley. The group controls the cutire Bashqul valley norlh of Kandesh, and has spotty control of the noighboring parun valley. The group is probably more accuraticly described as tribal than political--the people are all Bashoul Katis (soe Rerional Renort. lluristan. for more deLailed description of the aroal?.

For reasons lhat will he described bolow, most of the neighboring valley of parun las also vaceinaled. This area is controlled by a $\mathrm{mix}$ of llezb and Jimint as well as the above (3roup).

Nithough the people all cloarly identily themselves as Nuristanis. tribal differences within the area are still very significant. This is understandable aiven the geographic isolation of the different valleys: passess of up to joon meters 
soparate one valley from the next. nnother key factor in the merpeleration of liribal dfferences: ower unity i:s languales differences. The Nuristanl languages are ancient and bear no relation to Pashto or Dari. In Nuristan itsolf there are at least 5 different: languages. no more related to each other than french is to ttalian. In the space of one ' 7 hour walk, we passed 4 villages spoaking 3 different: lanquages-the local poople required translators to communicate with cach other.

The population in the Bashqul and parun valleys is probably in the range of 25,000-30,000. villages are numerous, and frequently wuilt on steep hillsides that cannot be tilled and are an asset to defense. The people are mostly farmers and sheperds, many. perhaps a quneter of the population, have a house or a room in a village where they stay in the winter, and a farm lo bhich they au and work in the summer. Villages are separated from each other by a one to four hour walk on a rocky footpatih.

though the area has not becn touched directily by the tragedies of the war. it has been affected conomically and culturally. Once very isolated, visiters, even nighans, requiring travel permits: now thousands of Mujahideen and refugees trek their way through Nuristan. As a result of trade with these travellers, numerous shops. hotels and chaihanas have sprung up. Once supplies came by jeep road from kabul, now the local men cross passes into pakistan two or three times yearly to get rice, sugar, cloth, cooking oil, kerosene and other neccessities for their families. Inevitibly, there has been profiteering from the captive market. passing through, with resultant inflation. Although outsiders suffer miscrably from this, many Nuristanis still exchange goods largely by barter, and thus are not so af fected by inflation.

To summarize. Nuristan is a qoouraphically isoliated, culturally distinct. agricultural region in northoast ntghanistan. The population is intact and controlled by a fundamentalist independent party as well as t.mational tribil customs. This is the area where the vaccination program was conducted. 


\section{THE VACCINATION PROGRNM}

TIIF, PLANNLD PROGRAM AND RAIIONM, FOR IT: Tho vaccination program for Nuristan was conceived after an initial visit to the area and a health survey which revealed an under $5 \mathrm{yr}$. mortality of 42\%. Iwo villages had described opidomics the winter of 1985 that reportodly killed about one-third of their young children. Classic pertussis symptoms were vividly rccounted. In addition, the Bashgul valley had not had a measles epidemic for 6 years. and in the fall of 1986, at the end of the first mission, measles cases were beinc reported in nearby chitral, pakistan. Therefore, it rass decided to mount an expanded vaccination campaign for the Bashgul valley on an urgent basis.

$\Lambda$ modified F.PI campaign was decided upon, giving DPT/augmented IPV, measles and BCo; to children Gyrs. and under, and 'I"r to all females 7-45 yrs. Killed ausmented polio (Merieux liabs. France) was choson despite its greater cost because of stability, ease of storage? (it does not have to be kept frozen) and its greater officacy after just two doses (Ref. 1).

Two vaccination rounds were planned (the maximum that time would allow), the first and the sccond course separated by a two month interval. This interval was decided on because it was the longest time that: be could allow, qiven the area to be covered and the time constraints imposed by the weather. Since greater seroconversion rates and higher titers are obtained after longer intervals (Ref. 2). and only two doses were planned, the longest interval possible was desirable. It was decided to give measles on the first round. and BCC; on the second because of the more urgent need for measles protection, and fears that the side-effects produced by BC(; would result in a greater dropout rate.

Tetanus toxoid was offered to all females under 45 yrs. This seemed more rational in an areas without ongoing medical services. Iwo doses of $\mathrm{ll}$ l' qive protection against neonatal tetanus for severai gears il. !). If repoat vacoination can be 
carried out in the next 5 ycars. women receiving 'I'l $\# 3$ should be protected for most or all of their childbearing years.

Several hundred $\mathrm{kg}$. of medicines werc also brought in. because it was felt that if curative services were not offered. vaccination turn-out or relurn might be low. The lion's share of the medications were iron. vermifuges, analgosics and trachoma antibiotics. "Preventive" type medicines were emphasized, but were not handed out systematically: only those presenting to the afternoon sick call sessions were given meds.

THE ACIUAL, PROGRAM. AND WHY CHANGES WFRE MADE: The original program was organized and put together bith a qreat: deal of urgency: the goal was to det into Nuristan as soon as possible in order to prevent an epidemic of measles. In this regard: the mission was a partial failure. Nlthough a vaccinating team was assembled and ready to make the crossing by March 10 , the aren could not actually be entered until over three months Jater, on June: 27. This was not from want of trying. Rexord setting spring rains, political problems in Nuristan, and the inexperience of the local people, on whom we had to rely. in handling "large scale" logistics. were all contributing factors. To mane just; a few things. floods, blizzards. D.R. $A$. government agents. Pak. border police and "the casual promise" made by Various $n$ fghan groups, as well as our own inexperience conspired against a timely cntrance. $n$ significant portion of our funds were expended in unsuccessful atlempls lo get in with various: groups and over different routes. This will be discussed further in the "Problems" section.

Once in Nuristan, we found. as we had feared, that a huge • measles epidemic had swept through the entire Bashaul valley. sparing only some farms and once remote villauce. Despite the fact that we did not arrive in the Bashgul in time to achieve 
the initial goal, it provided an opportunity to collect some

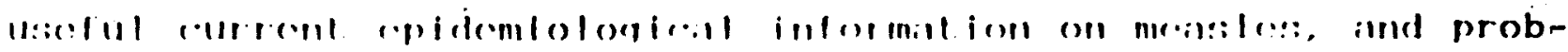
ably contributed to the high turn-out for lirst rourid vaccination in the valley. In addition, once inside of Nuristan, we heard that the neighboring valley of Parun had not been involved in the epidemic. Because communications in Nuristan are quite poor. it: was only by completeing our first round of vaccinations in the Bashgul that we were able lo establjsh that virtually: all the villages had been atlacked--we even encountered a few. children who still had rashes. To find out more about the next valley, we sent a team member who was from parun to collect information and see if the people would be interested in hosting a vaccination tcam. Meanwhile, we started our vaccination round: \#2. Thirteen villages, (about 2.13 of the Bashgul population). were offered scesond round vinceinilion. Overill, coverage rates of only $42 \%$ for women, and $50 \%$ for children, were achieved.

When our representative returned from the Parun valley. he informed us that villages there had not hat monsies for 2-7 years. Since offering measles vaccinc to a population needing it will normally save more lives than completeing DPPT and BCG--even with 100\% follow-up, we decided to proceed on into the Parun valley. Other significant fisetors in our decision were lhat the government of Anir Alral was providing us with much less than optimal support (see "Problems"), and the people of Parun valley seemed quite cager to have a vaccination program in their area. In fact, Wama, a very large and well organized village, had raised 50,000 afghanis $t o$ help us with our transportation costs.

'lhus, to summarize, initially a modified EPI program was planned, desiancd to provide the most complete coverage possible within pracetical 1 imitations. It. wass t.o cover a single geographic and political area, the Bashgul valley of Nuristan. The program was changed because second round coverage rates were lower than expected, and a recent measles epidemic: had rendered that vaccination unnecessary. The noighboring valley which 
83.

had not had measles was entered, and TTH1. DPPTHL. measles and BC: were given to an additional 1:500 women and children. This was felt to be a more cost effective plan. ndditienil factors were political instability in the initial region making it diffieult for us tes operale effectively, and active recruiting (Wama also sent us a representative) and orqanization in lhe second valley which encouraged us to modify our program.

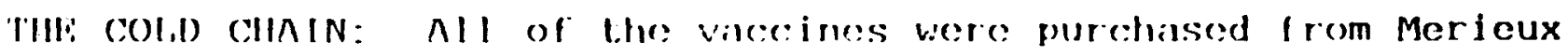
laboratory in lyon, france. Hericux airlreighted the vaccines. on schedule, with close telex communication to lakistan. on a direct flight from france to lstamabid. cusitoms clearance. was obtaincel in advances, the vacesinces weres unloaded within two hours of arrivill and placed in the eold room of the chief commissioner of Rofugees by his stalf in my presence. The vaccines were stored for 3 weeks therc, then loaded onto a truck in three biq Electrolux cold boxes and transferred to Peshawar. where they spent one night and then were flown to chitral in a plane.

In Chitral, the vaceines waited over three months for transfer to the inside of nlahanistan. burine this period they were stored either in the Electrolux cold boxes with ice pack changes as necessary to maintain the temperaiture below $8^{\circ} \mathrm{C}$., or they were stored in a refrigerator. In either case a record of the temperature was kept using an elcctronic thermometer. which could measure temps. via a probe. Lhus avoiding frequent opening of the refrigerator or cold box.

We were planning to maintain the cold chain inside of Nuristan using an Electrolux cold box/refrigerator which could run off of gas, kerosene, or electricity. Unfortunately, this refrigerator weighed $12 \mathrm{~kg}$. and was bulky. Despite the assurances oi our local transporters to the contrary, when it actually came to getting it into Nuristan. we wore informed that the width of the box, more than its weight or volume, provented it.s transport across a 4600 meter pass by a horse. The animal would not be able to navigate the niarow spots in the mountains. 
This we were not cold until the actuil time when the box was supposed to come inside--despite all of our cirlier checks.

lhus, faced with this problem, we decided lo ship in only enough vaceincs for the first round of vaceinations in the Bashgul, leaving the rest in chitral where they could be more closely cared for at the freedom lodicine clinic. The first course of vaccines were carried inside-28 kilos on a man's back in. a large Iffa Credo (Merieux) box. Although less robust or heat stable than the Elcctrlux boxes that we were plaming to use for the majority of the campaion. the Iffa credo boxes have the advantage of a shape that fits more casily onto a man's or horse's back.

Once inside of Nuristan we were faced wibh maintaining tho cold chain without benefit of a formal refrigoration system. Fortunately Nuristan is a cool mountainous region with summer. temperatures that rarely execed $25^{\circ}$ in the shade, where snow persists in avalanches and on momtain tops until september: and where the plentiful springs emerqe from the carth at:

$7^{\circ}-12^{\circ} \mathrm{C}$. We decided to take a chance on maintaining the cold chain for the first round vaceines using just the natural resources available.

As il Lurned out, we were: very lucky. Remembering a technique used by our grandparents to make ice cream on lhose long summer nights on the farm without electricity, we brought snow down from the mountains and mixed it with crushed rock salt. Snow during the summer in Nuristan is $10.0^{\circ} \mathrm{C}$, (surprisingly: its temp. is above freezing). By mixing the snow with salt and spring water $\left(3^{\circ} \mathrm{C}\right.$. usually) a slurry was made that, if sticred briskly, would descond to. $-5^{\circ} \mathrm{C}$. This is because saline (wiler and salt) freozes at $-13^{\circ} \mathrm{l}$. l3y mixing snow with salt, saline was created, the snow was melted which is an endothermic rcaction absorbing heat. and the temperature of the mixture was thus lowered to below the freezing point of pure water. Then it was a simple matter lo place ice-packs fillod with pure. cold ice water $\left(4^{\circ} \mathrm{C}\right.$.), stir briskly. and rrceze thom. The whole. process took $1-2$ hours in order to freeze ice for two cold boxes. The procedure had to be repeated every $\theta$ days to keep the lce boxes below $17^{\circ}-13^{\circ} \mathrm{C}$. 
Our Nuristani staff was able to master this procedure although they needed some supervision and never look the responsibility to plan and carry out the process on their own initiative. This method of mantaining a cold chain. although interesting. is too much work, is time consuming, and of course, requires snow. thus it is impractical for most vaccination programs inside of Afghanistan, unless conducted during the winter.

By october. maintaining the cold chain was mo longer a problem. Dilily hiqh temporatures did not usually exceed $14^{\circ}-15^{\circ} \mathrm{C}$. and nightly lows were in the range of $4^{\circ}-6^{\circ} \mathrm{C}$. The cold box was left open outside in a protected courtyard at night. and brought intes an unheated room during the day. llad we stayed longer. once it. began to freeges at night. ices packs alone would have been placed out to lrecze as noeded. lor winter campaigns. proventing the vaceines from freosing should not be a problem. becoause wood is plentiful and healed rooms are oasy to find. An unheated room sharing a wall wilh a heated room would probably: be ideal. Of course, constint monitoring would still be required by a responsible individual who understinds the risks of both: heat and cold exposure.

GETTING THE WORD OUT: COPIUUHTY FDUCATION AND MOBILIZATION A vaceination program was discussed with the head of the government, Amir Afzal, at the end of the first trip to Huristan. later planning was conducted by leleters hand carriced from pakistian to Nuristinn. The governmont, arranged for the transport of our materials to the inside by sending out. 35 men to carry supplies over the pass one beek prior to our crossing. llowever no actual community preparation was done by tho local government. and the poople received no command from their leader to come for vaccination (sce "Problems"). The suceess of the campalgn: depended on word-ot-mouth communicalion in most areas, and the faith of the pesople in the medical team.

Although initially we had planned to send a representative ahoad to inform the next village, in practice thiss was not, necessary: the communities virtually all knew of our presence from 
the moment of our arrival in the valley, and in most cases, they wore cagerly watting for us and knew exact:ly bhere: we were, how fast we were moving. and when we were expected lo arrive in their arca. Villages ofl the main track generally sent representatives to the nmir or to us. requesting us to come.

Upon arrival in each village. essentially he same procedure was used. The team would gonerally arrive in the afternoon, having walkod from the mrevious village. In almost every village: we were housed in the heme of the village chief. Upon arrival, while tea was being prepared we would ask for the village elders, mullahs and military leaders to be assombled and to join us for toa. Nlthugh the resnonse varied from village to village, in general it was good, better if we were sititing outside.

Once the men were assembled we explained why we had come, the importance of vaccination, who the tarqut population was, and the need for follow-up and repeat vaccination. The recent measles epidemic and the cradication of smallpox wore useful examples. Nll adults remembered the smallpox vaccinators and usually showed their scars. We explained that measles could be oliminated in the same wily. but to do so, new babies would have to be vaccinated each year. not just once as with smallpox. The smallpox scar was also useful in explaining the side-effect that would be caused from the BCo vaccillation.

We then asked the mullah or mullahs to announce our presence in the mosque, and we asked the men lo spread the word in the village and the surrounding farms. We asked that women not go to the fields in the morning. but rather to stay in the village for vaccination. This met with variable success. We frequently saw women leaving for the fields at 6:00, when we were just geting up.

In addition, either our first or socond night in each village in the Bashaul we passed house to housc doing a population and measles survey. This also served to inform the people of our presence and why we had come. 
12.

Each vaceination session began with a lecture using a photo poster of the six El preventible disenses. The lecture, which lasted about 15 minules. emphasized the recent measles epidemic, the offoct of lisecination on childhesed mortality. the need to participate in an ongoing manor with young bables coming each yoar. Side effects and the benefits of vaccination for pregnant women and newborns were also covered.

nlthough we tried to assemble the whole village for these talks. in practice this was not possible. The people simply would not come, sit down and wit.. We usually started when 20-50 men and children were assembled: more people came once thoy saw the postier and heard us talking. Homen nlways had to wit in a room while the lecture was given in the open air. nttempts were made to repeat. the lecture lor them, but difficulties were encountered because gonorally the translator was unwilling to address them direcotily.

Our goneral impression was thal there was interest in the lecture as a visual display, and that the poople appreciated our talking los them. Hewever Lheir participation was based not on understanding the principles of vaccination and its potential for preventing disease, but rather, on their faith in us, and tho value of our "pitcheories" (shots).

Vaccination sessions were held in the mornings and sick call in the afternoons. We stayed in most villages only two days, enough for two vaccination sessions. Ihis was not sufficient time to see most of the side effects produced by vaccination. llowever in most villages one or twe crying babies, or older children with $1 \mathrm{imp}$ from local pain were brethet in the afternoon. The children were examined, treated with paracetamol, and the parents were instrucled that local pain and tenderness was normal. In most cases the parents were open and did not seem overly concerned. 
CONDUCT OF THE VACCINATION SESSIONS AND THE SPPCIAL

REQUIREMENTS OF PURDAH: Nuristan is a very conservative area, reportedly more than many other parts of nfqhanistan, and purdah has become much stronger since the war, with the influx of strangers and the influence of Arab interests. Nevertheless women are not confined to the home: they are going to the fields every day.

Although our team had t.we expatiante women. all of our local team members were mon. We were occasionally accused of "violating purdah". This is an extremoly serious charge and one that must be avoided at all costs if women are not to be excluded from access to health care. The charge also puts the local health care provider at risk, and can be the reason for termination of medical services in the area.

On arrival in each village when we mot with the elders we usually discussed purdah and our desire to respect it. After the meeting we would go with a couple of village responsibles to look for an appropriate location for the morning vaccination session.

In most cases. we were able to find an enclosed courtyard with a room that let out into it where the womon could wait. We tried to find courtyards with two entrances so that the flow of traffic and onlookers could be controlled. Ideally both entrances were policed by local men who would limit the number of people inside to a manageable number. and ensure that poople left when they were finished. The courtyard was often divided into a registration and vaccinition area by hanging up blankets. The men were very helplul in this regard and could even construct entire" "rooms" made of branches and blankets in gardens in a half-hour.

Generally one man would reqister his entire family, be given the vaceination cards, and aftervirels he would return with his family. Then the family would be vacinated as a group, mitching cards to names, and kecoing back cards of people (women usually) who were reqistered but not pressent. ltsually Maria or I would have to vaccinate women ouer 14, although there were 
exceptions to this. Our Nuristani team members told us that if the local people did not have the option of having women vaccinators in the future. thint many more families would accept being vaccinated by men rather than missing out chtircly. This scems a little doubtful however. Getting slecves up high enough to vaccinate was difficult and time consuming due to modesty. Sometimes the men on our team would be asked to leavo the area, and they always had to be careful to have lheir backs turned. The most ingenious solution to this problem that 1 saw was in the village of Wama, where one of the village leaders who was helping us, seeing the difficulties we were having getting slceves up, got out his pocket: knife and quickly cut a tiny hole in the sloeves for the noorle lo qo through. The women didn't seem to mind a bit!

If the village mullah was interested in vaceination we could sometimes get him to be present during the sessions. We welcomed his presence, because it gave il stamp of approval to women coming for vaccination and it helped to protect us from unfounded acousations of violating purdah. Whon the mullah, village chief or other responsible mon got involved in helping during the sessions this male our tasks easier. and always im- . proved the turn-out. 
TRAINING OF LOCAL VACCINATORS

Developing a tcam of vaccinatiors capable of carrying out future campaigns unassisted was a priority for this mission. Establishing a network that can deliver future vaccination services is the logical extension of a mass campaign, and it is almost impossible for lirge enough numbers of foreign teams to enter resistance controtled areas to have an impact on the population as a whole. The F.P.I. program worldwide depends almost exclusively on trained local vaceinators.

Our Leam had four student.s. Three were from the Bashgul valley. and one was from Parun. Two of the students had been handing out pills, giving injections and pulling tecth for some time prior to our arrival. although they had never had any formal training. nnother was the son of a medic who had been trained in lesshawar. The father had worked in Nuristan briefly before dying of appendicitis. The son. however had no medical experionce, and neither did the fourth student from Parun. One student had finished grade $1 \%$ prior to the war. Although the otheres also clitimed to have completed "highschool" by yoing out to lakistan, they seemed to be closer t:o an 8 grade level.

Training was primarily on the job. Sit down, didactic sessions suffered from time shortages. short attention spans. and the frequent: need to translate into two languages. Attendance was also spotty. Attention was better, as it is with all of us, when the students had their hands on the equipment.

The students readily mastered daily temperature checks on the vaccines, and proper lil injection technique. On our arrival however, when we were assured that two of the students "know how to give injections". we found that they aimed for the mid-buttock, just at the level of the sciatic nerve, and had no idea how to properly sterillze equipment.

Imojels were used for the rirst round of vaccinations in the Bashqul. The heads were boiled aach morning for 15-20 
minutes in a special teapol. a spoonful of vinegar having been added to the water to precipatate out the salts. After each session the heads were disasscmbled. cleaned in water and qreasad with silicon. Ihe students were very excited over the imojots, and they were eager to demonstrate their abilities, sometimes without sufficient practice. Shortly after the students took over responsibility for assembling the imojets, one was misassembled primed, jammed and then frozen closed.for over a week until a way could bo found to unjam it.

Especially with the younger students, the interest in gadgets and giving shots did not extend to the more mundane aspects of the program. Two students did not master registration of . tho population in a systemic and reliablo manner. Daily tasks such as temperature checks and boiling equipment were understood by the students, but would be done only when specifically told t.o do so. Getting the students to assume responsibility for daily repetitive tasks was not very successful.

A particular problem was syringe disposal. We used all disposible syringes, burning them at the end of each session. We frequently witnessed men appronching a student going off to burn the syringes to request a fow "just for the animals". Although there was no intellcctual problem in the students understanding why dirty needles should not be reused, in practice. they cannot resist the pressures of their society to hand them out.

When wo went on to the larun valley. our sludents from the Bashgul did not go with us. They were afraid of the different tribes, and also, with good reason, of what their own people would do once lhey returned. likewise. lhe student from parun valley was eonstantly questioned and sometimes harrassed by the population of the Bashgul. The lack of accoptance of "outsiders" was especially manifest with regard to purdah.

clearly. from the above discussion, we were disappointed in our efforts to train vaceinators. Three of the students achiceved no real level of competiancy. The problem was not in understanding, rather, it was a lack of maturity.' compul- 
sivity, and initiative--coupled with a powerful closed society applying pressure to perform dangerous medicine that, realistically. a mere individual has greal difficulty resisting.

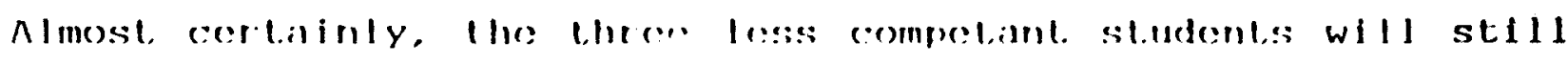
make use of their experience with the foreign team to "practice medicine". of coursc. Lotally unterained people are handing out meds all over Afghanistan and in many other parts of the developing world. However. I am afraid that more harm than good is done by these practioners. and it bothers mo to have now provided oursa certain "cloak of competance".

The good news is that one student. the one in his late $20 \mathrm{~s}$ who had really completed 12 grades, did develop a level of competancy. Although he would require more training, he is one potential future vaccinator. In addition. Mohammad Ni, the Nuristani "Minister of Information", and Abdul, our Kalash manager, who are in their mid-thirties, both mastered the vaceination process, and eould be relied upon to carry out an effective program. Unfortunately, both have other duties and are not interested in becoming future vaceinators.

In conclusion, it was the impression of our team that, if a short period of training ( 2 mos or less) is to be successful in developing competant vacoinators calable of functioning independently, then the people chosen must be mature, compulsive and starting from a high educational level. If the only available students are young and have less than a high school education, then a more extended course of study is more appropriate.

In areas such as Nuristin. where there has been considerable "brain drain" and where the original population had a very poor educational base 10 stiurt wilh, most students will need longer training before they can function independently in a safe and reliable manner. In addition. the likely role the community will assign to them. that of hoalers, cannot be ignored. For this reason, it is most, prudent to offer vaccinator training to adults who have recoived or are receiving other medical training. 
18.

Another alternative is to send minimally trained vaccinators to areas where they can work in association with and under the supervision of already cxisting health care toams. In this setting. vaccination services can serve as an extension of the existing health network, the work can be overscen, and the vaceinator, having a referral conter avaliable, will be loss tempted to overstep his level of competince. of course. although there are many groups striving to alter the situation, in rural NGhanistan today. thore are very tow existing modical networks.

If solf-destruct, non-reusable syringes become avallable, are cost-effective and can be implemented inside of Afohanistan (hopefully by late 1984). ihey should go a lond way in helping prevent the more dangerous effects of the uncontrolled "medicine" that goes on inside. If this type of syringe can be implemented. then training large numbers of vacelnators in shorter courses becomes not only leasible, but also more responsible. One of the most danacrous effects of uncontrolled medical practice. that of syringe reuse wilh the concomitant risk of possible nIDs and other disease transmission, will be prevented. 
Relicef and dovelopmental work in Mfghinistan is frought with special difficulties. The war. Lhe geography, the tribal culture with its ancient divisions all poso special problems for this country which is one of the least developed in the world. Mounting cross-border aid without the benefits of an orqanized government infrasteweture, without fransportation or communication networks is an chormous challinge. Problems can occur on a daily basis and are frequently. large scale. This section will touch on a few of the more commonsbigger problems, and when possible offer suggestions on how to deal with them.

Delays occur almost everywere and with every group. In the Nuristan project, nearly 4 frustrating months separated our first attompts to get in from our final successful entrance. Although this delay is remarkible, other grouns have waited longer, and some missions have been scrubbed entirely due to delays. Repented attempts to mount a mission, and periods of waiting add cnormously to the overall cost, representing a hugo unseon sink for funds. The calusc:s are: multiplo. Because transport depends on nlahans, their experionoe, or lack of it. are key factors. Mlso their sonse of lime and soheduling are very different from our own. The same individual or group may be responsible for all the tramsport in a region. ns such they may places higher priority on arms or other maleorial transport than humanitarian. Additional factors are political instability due lo the war or lo resistinces infighting that affect either the region or the route: and in many arcas, the weather.

To illustrate, here is a summary of our aticempts to get inlo Nurislan. In November 1986, afler discussing the possibility of mounting a vaccination campaian with tho Nmir and getting his pledae of support. two or three local representatives were met with to discuss the possibility of entering Nuristan during the winter. Assurances were given that a team with equipment 
could cross a low southern pass into Nuristan with the help of the Dawlet even in mid-winter. The pass discussed had been crossed by a medical team in february a few years earlier. (un this basis; a mission was mounted.

The expat. team arrived in Pakistion in carly February. Upon arrival the Dawlet office in Peshawar was visited. We found that the representatives had changed, and knew nothing of our planned mission. In addition they told us that the Dawlet did not control the pass in question and they could not guarantee our entrance into Nuristan until the higher passes opened in June.

'Thus, we initiated contact with Jamiat and Hezbi (Gulbaddin). Both groups had access to the region. Jamiat travels through Nuristan to get decper inside and so has agreements with lawlet. Hezbi is very influential in southeast Bashgul, and controls the entrance just next to the garrison of Barikot. The political officers with whom we had contact in both Jamiat and Hezbi were helpful and introduced us in short order to their respective commanders in the area. Both commanders were eager to help a medical team go inside since our team would offer services in their area as well as the adjacent Dawlet arca.

We chose to go with the Jamiat commander who said he had 100 men under his control, rather than llezbi, because relations between Jamiat: and Dawlet are better, and we were afraid that once in a llezbi area they would not actuilly allow us to leave and enter the Dawlet area where we wished to go.

the team and equipment. were moved lo chitral in early March. Severc weather--the worst the area has seen since the beginning of the war, forced two loam members to walk over a pass rromm Peshawar to chitral that was elosed to road traffic, and caused us lo rent, a private plane lo get onc ton of equipment in place on time. The Jamiat commander arrived one day after the toam and equimment. but arrived saying that he had only 4 mon at his disposisl. not, 100--just: like that, no further explanations were of tered.

In addition, at about that time we received word that 
the DRA had sent two Nuristani government aqents into the region - which had recently been bombed. with the aim of getting the area to go over to the qovernment side as part of "national reconclliation". Nlso while in chitral we were lold that the llezbi commander we had becn offered las a clandestine agent of the government. Although such reports cannot be confirmed. obviously it added to our doubts.

nt that point, blocked by record setting rains and political dead-ends. the first. team was sent balek to furope, while Abdul and I continued our of forts to orannize an entrance.

The above history probably conveys the difficulties sufficientily well so that other detilils are not really necessary. So, suffice it to say, that. contanel, was also made with NIFA, only lo find that their comminder wass a member of a family that had been expelled from the area due to tribal.war: the border police apprehended 12 of our bags that were crossing close to Barikot via an independent transporter. Amazingly. the bags were later released to nbdul. other bags and receipts were lost in flooded rivers during torrential rains. Not to be forgotten were "secret agent:s" who caused problems by intimidating transporters and tipping of the police. We finally decided to quit trying and just wat until the high "Dawlet" passes opened-which they finally did after much delay due to bad weather.

Thus, after all this, sponsurs sent another team from Europe. In the third week of June, with a combination of 35 porters organized by Mohammand $\mathrm{Nli}$ and sent out from Nuristan by $A m i r$ Azal, plus 17 independent Kalash transporters arranged by Abdul, we were finally able to make our crossing over a 4600 meter snowy pass into Afghanistan. The six kilo opium bust which happened the night before our departure which caused us to change passes literally at the last moment, and the border guard who happened to hitch a ride in the same jeep I had rented in my birka are not even worth mentioning. 
What can be done to deal with the problem of delays? First, realize that a certain number are inevitable. In Afghanistan, more than in other areas, expatriate team members need to have a flexible, extended period of time free. The team leader needs to be in place in advance of the team arrival, and needs to address all details of the current political situation and as much of the logistics as is possible.

In addition, it must be realized that statements and promises from the vast majority of local groups and individuals mean very little indeed. Saving face, or looking competant or powerful to their local peers is much more important to most Afghans than carrying through on promises made to westerners. of course there are excoptions to this, especially with more sophisticated individuals. However, except where long experience with a particular group or individual has proven otherwise, it is best to cnteltain all promises or guarantees made with a high degree of skepticism.

As is quite apparent from the above description of our attempts to get into Nuristan, everything must be cross checked and investigated carefully. Still, in the conditions of war, with the constantly changing circumstances and in the absence of a qovornmont, dolays are inovitible, should bo expected and planned for.

Managing logistics is another serious problem in Afghanistan, and one that also contributes to delays. Although nfghans have expertise in transporting their own materials, they lack necessary experience in the special requirements needed for the transport of medical materials. Traditionally; animals transport small flexible packets of foodstuffs or household materials in saddlebags. Medical supplies are frequently in square metal boxes to protect them from rain. These are very difficult for the animals to manage, as good pack saddles do not exist. Dolicate matorials such as gcneratiors or refrigerators have to be proteceled aginint. krocks or falls or spills in rivers. The sun and heat exposure are often important. 
Managing a tight transport schedulc, as is necessary with vaccines, can be critical. Animals must be found and either rented or bought. In either case they must: be fed and cared for. finding fodder and conscionlious hor semen isi alwiss difflcult; profiteering and inflation are constant unwelcome companions--as in al1 wars.

In areas where motor transport is not possible. the prob$\mathrm{lem}$ of logistics is best handled by having a full-time experienced person especially hired to maniage this task. He should not have other responsibilities. Logistics is really a full time task which is frequently overlooked, cannot be managed by horseman, and thus becomes a daily thorn in the side of the entire team. Successful management of logistics is essential to prevent recurrent delays and unnecessary stress in the team, and between the team and the local population.

Another problem that must be dealt with in Afghanistan is the political situation. This has many aspects. First, there is the relative lack of organized leadership within resistance controlled areas of Afqhanistan. Evon where military leadership is well established and relatively professional. this very rarely extends to social and community organization outside of the immediate exiceneics of wir.

Medical or developmental projects will be most successful in areas where the political situation is stable, and where the leadership is strong and committed to developmental work: as a priority. If a strong leader commands his people to come for vaceination, response will be greater, and the program more successful. If the leader is sufficiently organized and committed to also provide logistical support to the developmental team. then their work will be much casior, and the chances of a long-term or permanent developmental proqram being. established will be much qreater. One of the goals of most cross-border work is to provide some kind of permanent developmental network. but this is rarely possible due largely to the relatively unstable political situation.

nnother aspect of this problem is the constant flux of the political scene. Even the most carofully planned and well 
thought out mission can fail if either the target area or the area through which the mission must travel has become unstable.

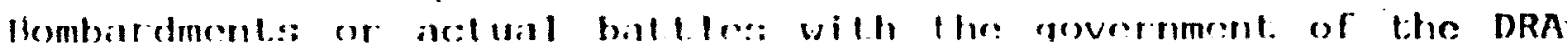
are the most obvious examples and are usually well publicised and easy to find out about. even in lakistan or Furope. Much more difficult to gauge, but equally important to the success or failure of a mission. are tensions betwen various resistance groups which may erupt into ambushes or outriqht battles, tribal warfare, or clandestine quvernment infiltration and destabilization of a liberated area, or the influence of other groups, such as the anti-western fundimentalist Wahabis.

For instance, in the Bashgul valley of Nuristan, the area has been under the control of a single loader for six years. It has a stable government. with many funclionaries, but there. is little evidence of work that gets done in terms of community services. Nithough our vaccination project only took place as the result of a preliminary mission during which a vaccine program was agreed to by the amir, and received his pledge of support; when the program actually took place several months. later, the situation was quite changed.

The government assisted us in moving in our supplies. thus. we felt. siqnallind their support for and willingness to participate in the realization of the mission. However. two days prior to our arrival, unknown to us, and perhaps also without notifying the amir, six fundamentalist wahabi representatives from the middle east had arrived. Nuristan is a region that recelves a large amount of ils support from. Lhese groups. The Wahabis have had considerable success in influencing the behavior of the population (changing the style of prayer. for instance).

During my first trip. no representatives of the fundamentalistic middle eastern financiers were present, and the population and government welcomed a plan for an expanded western. medical mission designed primarily to serve women and children.

llowever, the unexpected simultancous arrival of our team and the Wahabi representatives caused an cnormous problem in 
the area. It was clear that pleasing the Wahabis was very important to the local government. They brought money, and were aggressively hostile to westerners. We suddenly found our position in Nuristan completely eroded: wo were not even received by the anir for the first three weeks of our trip. logistical support and lodging were intermittantly given then withdrawn for no apparent reason, and extremely minor infractions of purdah suddenly became raging issues. We were repeatadly physically threatened by some of the Wahibls, who were trying to force us out. We were often defended and protected by the villagers, but never by the government. Thus, due to a quirk of fate, but a quirk that is not a rare event in this country at war, our work was rendered much more'difficult: in fact. we were lucky that the mission did not fail entirely.

Experiences such as ours are not isolated or unique, many other western groups have experienced various forms of political instability which has interfered with, and sometimes prevented the realization of projects.

The unstable political situation in nfqhanistan is a problem area over which we have little or no control. of course, having the most complete and current information, and if possible from multiple sourcess, is very useful. In addition, when organizing a mission, oblaining written statements from the host government will often carry more weight and be more likely to be honored than verbal pledges. Mlso', every effort should be made to work in areas where the leadership is dynamic, interested in the welfare of the population, and willing to parlicipate actively in developmental work. If possible, a backup, alternative area should also be planned for, in the event that instability in the primary area renders the project unfeasable, so thist the entire project does not depend on events in a single area. 
BACKGROUND: One of the least developed countries in the world even prior to the war. Lhore has never boen extensive epldemiological information available concerning rural Afghanistan. The war has caused almost a complete stoppage in the collection of demographic and health statistics. However, this information is vital to assessing the effectiveness of health care programs. and gives importiant direction to the planming of future work.

The data presented here was collected by non-professionals, not trained epidemologists or statisticians. In addition. our time and energy were quite limiled. Novertheless, some useful information can be obtained.

SCOPE: The enclosed first roport on Nuristan contains information on prevalent diseases as vell as maternal and child mortality. The information collecled during the second mission was designed to complement that of the first. Since the primary purpose of the second mission was a mass vaccination campaign. collecting domographic information to assoss the percentage of population covered was a priority. The recent occurance of a measles epidemic provided us with an opportunity to collect some current datia on that discase. for several reasons we chose not to keop detailed records of the approximately 6000 persons that we saw in sick-ciall sessions. *

METHOD AND ERRORS: Demographic: informalion was collected by a toam member working with a local represculative in each of 16 villages. linch house was visited, and gonerally a member. of the household would serve as informant. In some cases.' however, when the family was not at home, or was spending the

* other groups have collected this type of information more accurately than we were able to in our quick passige from village to village. Most of our patients were curious locats who were not acutely ill. Thoy were soon guickly and received analgesics, verifugess, vitamin:s or iron. We decidert to offer sick-call as a moans of increasing public: confidences and encouraging turn-out for vaccination. Keeping records on patients" complaints is time consuming. and probably would not have contributed meaningfilly to an understanding of disease prevalence. 
summer on an outlying farm, information would have to be obtained from a neighbor or from the village representative. Each informant, was questioned reqarding the number of family members. the number of children and their aces, shether they had had measles, and for children who had died, how long they had been sick. In many villages. families were also questioned about whether they lived in the village or on a farm during the summer, and whether they had brought their children for vaccination. Due to the eonstraints of the socicty, information was not collected on the number of women of childbearing age, and whether or not they had eome for vaceination. Nll persons vaccinated were first recorded in a contral reaister. Data on the percentage of the population coming for vaccination was derived from a comparison of numbers vaceinated to children under six recorded during the population survey.

The statistics are skewed in the direction of showing a higher percentage of coveraue. While most of the population lives in the villages, going out to the noarby ficlds and recurning at night., porhaps 10-1!n live full-time on their farms. lhese people were not counted in the village population survey. but may have walked into the village for vaccination, thus affecting the statistics.

Anothor source of error that was apparent to us was in determining chronological ages in the population. Although parents soemed to know their children's ages quite: accurately when the kids were less than a year old. lin dretermination of

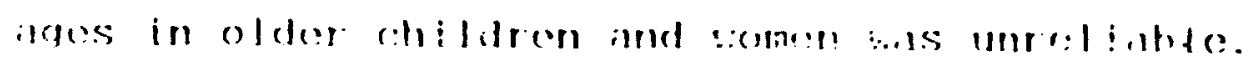

lhe measies survey uvei ise: bis true incidence of measles in children less than 6 menths of age. The presence of maternal antibody in infants protects lhem, and it is extremely unlikely that more children died in the under 6 months category than in the 7-12 months category. Nithough many parents claimed that their young infants who died had a characteristic rash, the presence of a rash was not asked about systematically, and probibly miny of these children aletually diced of other causes, such as unrecognised neonatal tetanus or pneumonia. 
RESUI,TS:

1) MENSLES SURVEY: $A$ survey of 16 villiges (population: 6765) demonstiated that measles attacked virtually $100 \%$ of

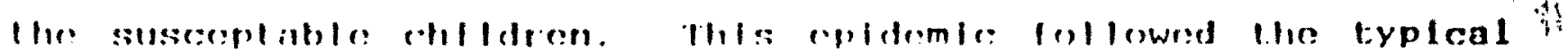
pattern: practically all chllden older than one year who had not been previously exposed came down with measles.

of the 1904 children who became il1. 266 of them, or 14\%.) died. (Charts 1 \& $\quad 2)$. Mortality was highest in the youngest age groups: children less than a year of ane had a case fatality rate of over 40\%. For children $1-2$ years of age $1 t$ was 337. while for older chlldren the disease became much less severe. With fatality rates of 12 for $3-4$ year olds, and $6 \$$ for older children. (chart 3). The average duration of lliness In lat.al casses wass 1 to 2 wooks. (chart: 1$)$.

Although measles normally strikes every $2-3$ years in most unvaccinated third world ponulations. In Nuristan the Interval is much longer. In a couple of villages, many chlldren up to 12 years of age became 111 . This long interval is most likely due to the geographic isolation of the villages, and tends to protect the population, as age and case falality are inversely related.

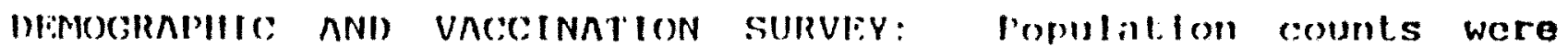
done in 11 villages--representing about one-thirdy of the vil-; lages in whleh we worked.

In the 11 villages studied, aprestmalesly out of the targot: children were brought. for vaseimilion. The exact percent of target women who same for testames vace:ination an the first round is unknown however, becausse the: number of lomales under 4h yoars was not asked lor in the populialion survey. Making an estimate bassed on derived datii, il. appearts thist the percentage of women vaceinated in the first round was also very high. in the range of $90 \%$ or higher. *

Unfortunately, the levels achieved for the second round were much lower: $50 \%$ for children, and $45.8 x$ for women. (harts 5 \& 6). The reasons for this were multiple. Most appar ont to us were: 
1) Timing: the second vaccination session occurred during harvest.

2) laack of eomprehension of the purpose of visecinistion: not

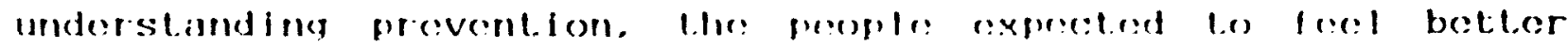
after the shots, but some actually felt worse.

3) The novelty had worn off: the villagers were less curious about our presence when we returned the second time.

4) Fears that the vaccinations might bo harmful: in one village. 2. or 3 miscarrages occurred after our first visit, and there, no one came for second round vaccination.

Tallying the ages of the vaccinees, we founif that there was somewhat of a tendency to not bring very young children for vaccination. (Chart 7). The belief that "the shot is too strong for the baby" is conmon in much of the developing world, and can account for extremely low turnout in babies. We emphasized repeatedly the need for even newborns to be vaccinated, and this probably explains why the number of infants brought to us was only slightly lower than would be expected demographically. Ihe distribution of womon vaccinatied also appeared to concur to the actual expected age distribution in the population. (Chart 8 )

* In the 11 villages the total population was 3782. Subtracting children 6 and under (1264), qives 2518 adults. and if half are women then there are about. 1260. 12.33 women were vaccinated in these 11 villages. Aginin. the uncounted people living on farms and coming for vaccination must be considered, thus the true percentage vaccinated is lower than sugqested by the figures. 


\section{CHART \#1}

WEASIES INCIDENCE NND (ANSE FAIALITY BY VILLACE

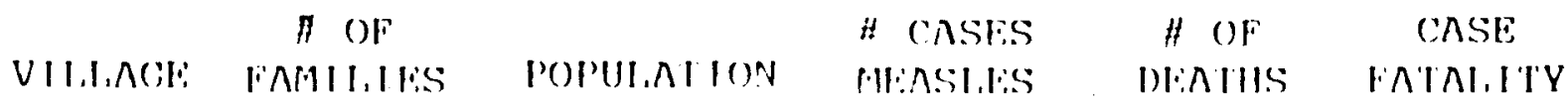

1 i MNNDNGAL

$338 \quad 259$

$51 \quad 21 \%$

2. BAMANDAGAL 34

219

50

$B$

$16 \%$

3. PnPruk

149

851

35,5

65

$18.5 x$

4. POIYYRUSTAM 37

200

71

4

58

5. CHAPO

67.

309

62.

6

$10 \%$

6. AULIGUL

29

70

3

47

7. BARGAMATAL 161

969

215

12.

1. $6 \%$

8. CHIT'juls

97

573

12.7

11

$8 \%$

9. nP'Tsn I

62.

403

10. PESHAWNR

79

466

9

7

$7.1 \%$

11. DIWกNกBABA $2 \%$

176

1283

30

$2.3 .1 \%$

12. AT'TE'I

$?$

174

7!)

9

12.

13. AZOOK

46

286

14. GUNDI LUKSHAL, 51

450

50

7

$14 \%$

15. I,UI,UK

.38

284

82.

7

$7 x$

16. P'ICHIGROM

40

259

2.5

13

66

67

i

$7.4 \%$ 


\section{(IINRI $\# 2$.}

OVERALI, MEASIISS CASE FNTAIITY

IN 16 VILLACFS IN NURISTAN. 1387

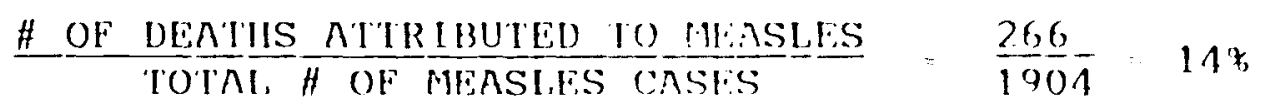




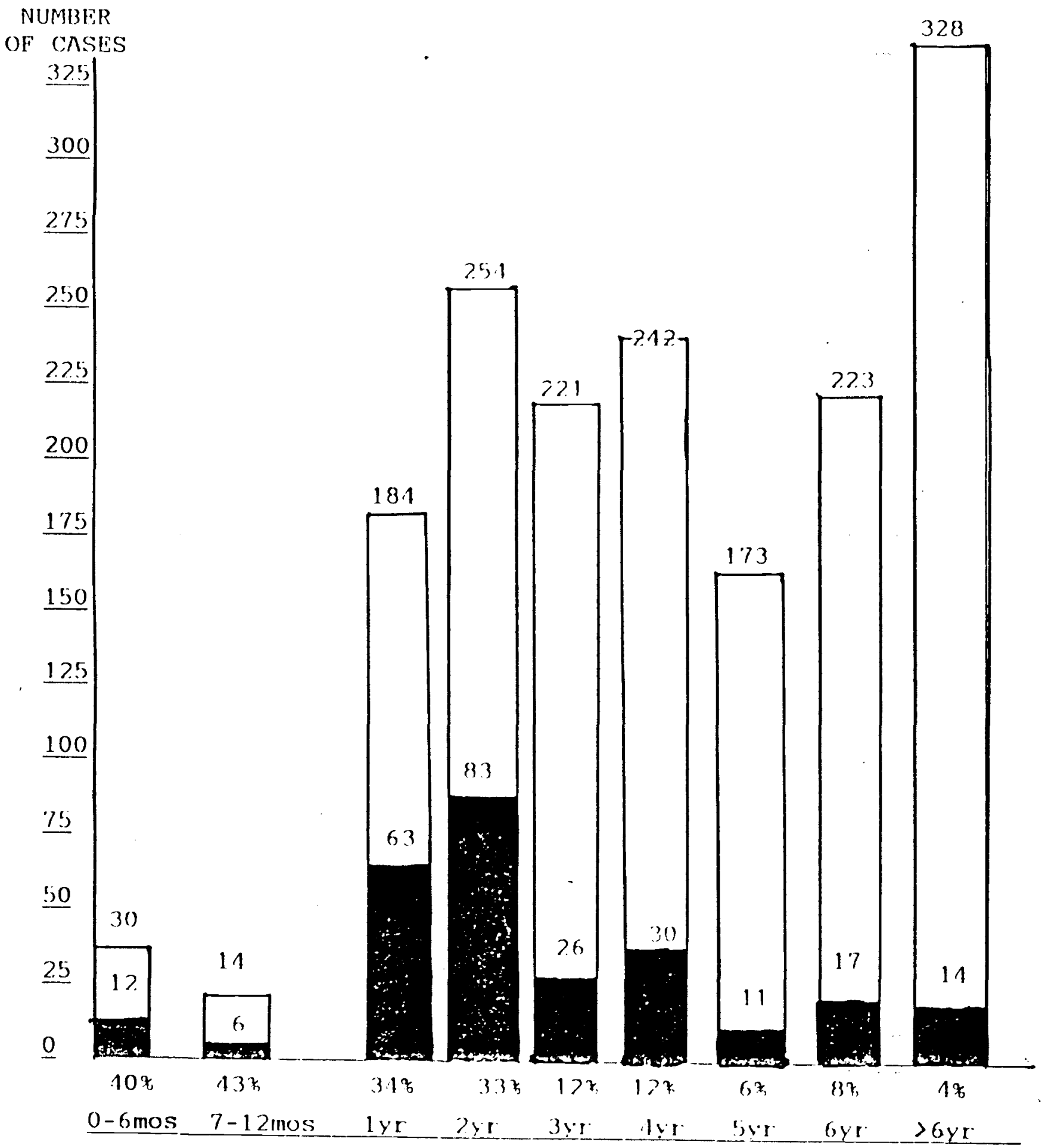




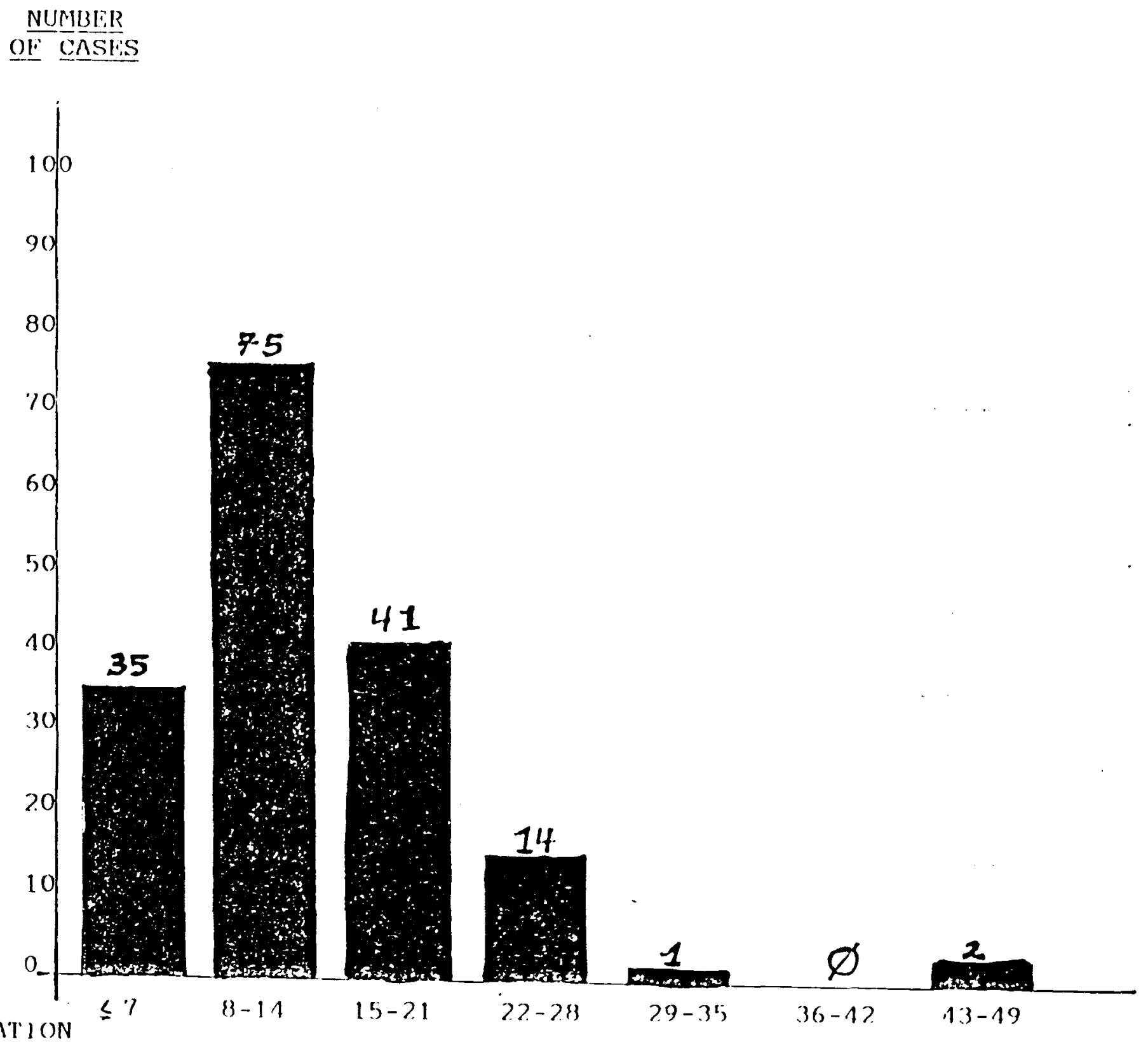
IF ILINNESS TN DNYS 


\section{RESPONSE TO DPPT \#I AND \#2. BY VILLAGE}

\begin{tabular}{|c|c|c|c|c|}
\hline VILLAGE & $\begin{array}{l}\text { CHILUREN } \\
\leq 6 \text { YEARS }\end{array}$ & DPPT & DPPT $\$ 2$ & $\begin{array}{l}\text { 2nd ROUND } \\
\text { क OF } 1 \mathrm{st}\end{array}$ \\
\hline nULIGUL & 30 & 6.1 & 31 & $53 \%$ \\
\hline
\end{tabular}

2. NIK MUK

?

103

33

32.8

3. BADINSHAW

$?$

$5 !$

41

$11.5 \%$

4

BARGAMATAL

234

135

142

$73 \%$

5. CIII'TGUL

145

116

6,3

$11 k$

6.

nelsn I

120

1.36

30

$66 \%$

7.

PESIINWAR

143

121

53

118

8.

D) WАNABABก

80

101

69

667

9. ก'ThI'I I

$5 \%$

4!

10

$22 x$

10

119

3.1

50

$59.5 \%$

11. GUND ILUKSIINL,

141

103

$2 !)$

$21 \%$

12. LULUK

72

78

11

52. $5 \%$

13. PTCHIGROM

78

73

0

$0 *$

TOTAL

1264

1307

651

$50 \%$

Estimated percentage of children coming for first round vaccination:

$\frac{1307-(103+55)}{1264}=$

$$
\frac{11}{1264}=91 \%
$$


RLSPONSE TO TR HI NIII TI H2 BY VII,ISCE:

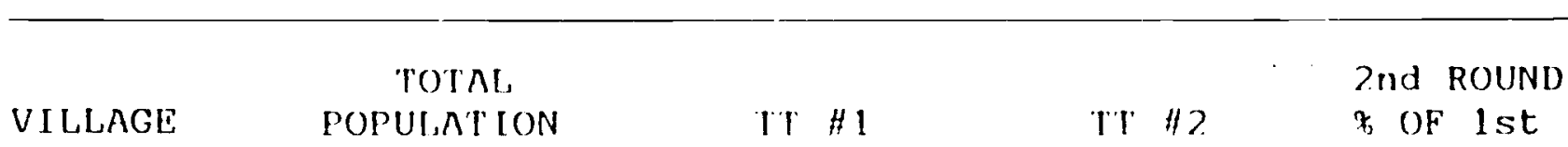

1. NULIGUL

208

63

26

$11.2 \%$

2. NIK MUK

?

39

26

$26.3 \%$

3. BADINSIINW

$?$

1,7

.39)

68.43

4. влRGNMNTAL.

969

2.43

161

$66.3 \%$

5. CHITGUL

573

165

76

16\%

6. $\Lambda \mathrm{P}^{\prime} \mathrm{TS} \Lambda \mathrm{I}$

103

170

97

$66 \%$

7. PHSIINWNR

466

$10 \%$

36

$33.6 \%$

8. DIWANกBABA

176

123

67

$54.5 \%$

9. กTTET I

174

73

2.1

$28.8 \%$

10. $\wedge Z O O K$

2.86

103

66

$64 \%$

11. GUND I LUKSIINL

450

$73^{-}$

12.

$16.4 \%$

12. I.ULUK

284

69

30

$43.4 \%$

$$
13
$$

13. PTCHI GROM

259

9.1

2

$2 \%$

TOTAL

3782

1433

65,5

15.88 


\section{MGE DISTRIBUTION OF $105 \%$ WOMEN RIECEIVING TT HI}

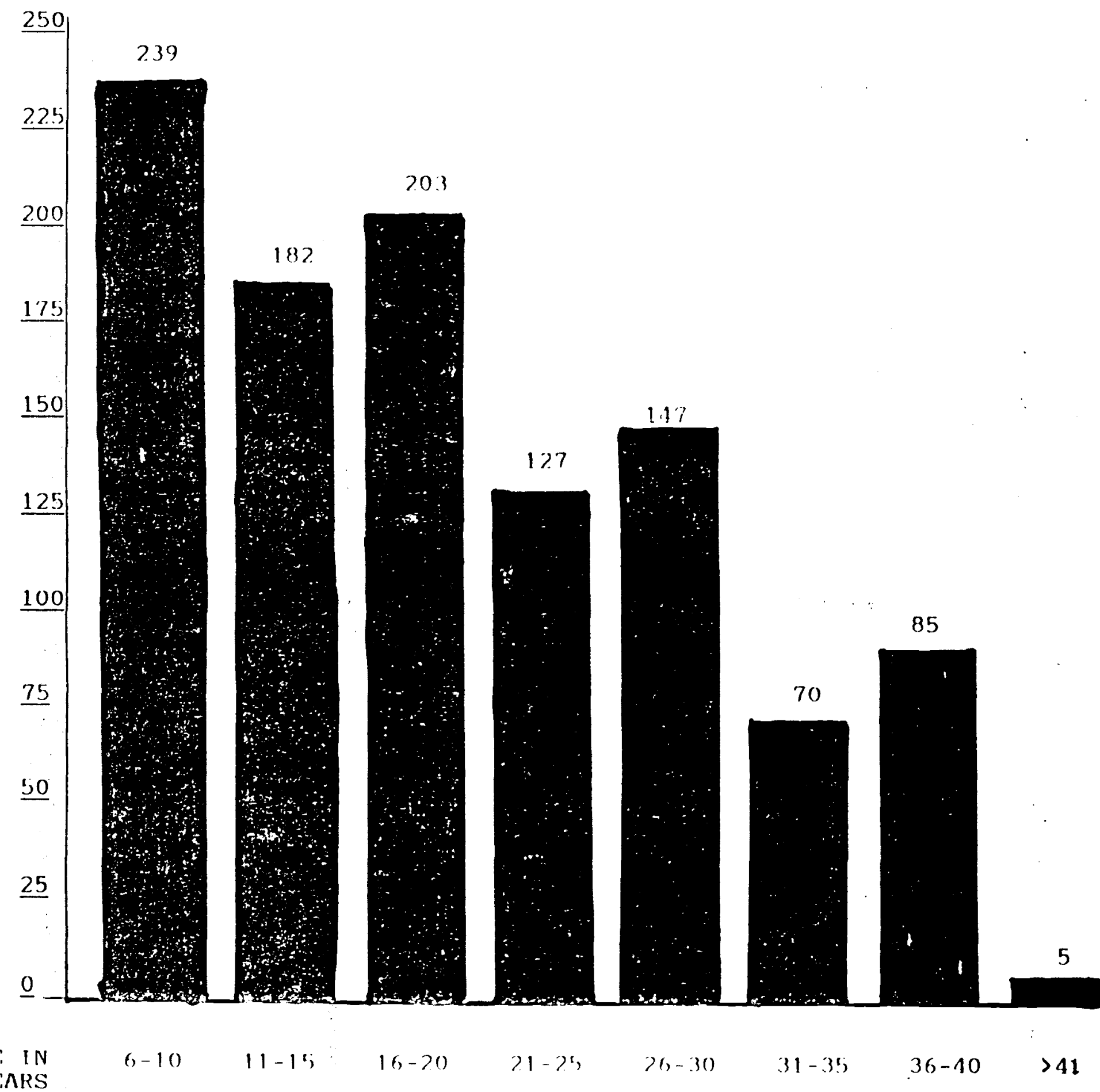


In terms of technical considerations, such as maintaining a cold chain, mobilizing a sianificant portion of the population and vaccinating them. this mission can be considered a success. With some modifications die to the particular circumstances found in the aroa, the campaign met its initial goals. We were not able to arcomplish a more long-term goal however: the institution of a network capable of providing ongoing services in the future. To accomplish this, working in areas with stable and hiqhly motivated loadors should be hel pful.

The events that occurred during this compaign raised many evocative. difficult questions. For instance, what can we do to improve second round vaceination turn-olit? In nfghanistan. sosial, cnutronmontal and political factors are more importint than modical considerations in choosing the proper time interval belwesen varerinatiems.

What can we do to develon a cadre of health care workers who can contribute meaninglully to the welfare of the populations they serve? Our potential for doing unintentional harm. must also be carefully examimed. This pertains not only to the potential harm of medieines such as chloroquine or dirty injection equipment. but also bo more so-called esoleric questions: what impact will vaccination have in aroas with a fragilo ecosystem and a pomulation extremely resistint to practicing birth control? What impate will heallh care providers have on the political situation in the aleat llow can developmental work encourage the growth of responsiblity and independence rather than a welfare "hand-oul" mentality?

nnother interesting consideration is the relative cost inefficiency of developmental work in nfghanistan when compared to other third world councries. It scems unlikely. given the circumstances, that most missions will bo cost-offective in 
terms of cost per child vacoinated. Ironically, there is money for Afghanistan now bocause of the war. hopefully significant

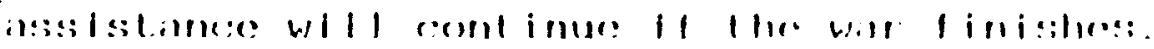

Developmental work in hfghanistan is important and must continue. Most of the dificult questions posed above have no answer. By asking them I lo not mean to discourage others. the questions merely reflect some of the concerns that developed for me during this project. ns such, they seem sonchow valid Lo present in a conciusion. and are not moint to offend or discourage the reader, but rather to offer a few considerations that may help in structuring luture missions. 


\section{REFERENCES}

1. "Simplifier les Calendriers de Vaccination en Afrlque de l'Ouest" by Philippe Stocrkel

Carnet, de l'Enfance. Vol63!72. 1985 p. 343

2. "Diptheria \& Tetanus Tuxoids and Pertussis Vaccine, Combined" by Orenstein, Weisfeld, Halsey

Recent Advances in Immunization 1983

3. "The Use of Tetanus Toxoid for the Prevention of Neonatal Tetanus in Developing Countries", by T. Stephen Jones ibid. Ref. 2 


\section{ACKNOWLEDGEMENTS}

So many individuals have given generously of their $t$ ime and talent for this project. Services and donations in kind were provided willingly by many persons and groups. But the following stand out.

Hannica and Anders Fange, whose careful questions, advice, and vote of confidence provided the necessary moral support to enter Afghanistan the first time as an unsponsored individual. The early technical and financial support of the SCA made the second mission, the vaccination campaign, feasible.

To Jack liesar, Moruim Rahmanzai, Al Nehoda, Larry Crandall. - Tom Goutierre and Brad llanson, many thanks for sharing their expertise and counsel when $I$ was a newcomer in Pakistan.

Philippe Truze gave his unqualified support to this vaccination campaign. He shared freely his technical experience. opened doors for me with his associates and collegues whom he had gained over long years of committment to Afghanistan, and provided invaluable assistance in fundraising.

Thanks to the staff of MSF, especially Juliet Fournot, Eric Laurent, and Didier Lefeure for their technical advice, experience, support and encouragement.

The staff of the Pakistan chief Commissioner of Afghan Refugees made a special effort in rapidly and efficiently clearing the vaccines through customs and into their cold room. Dr. Shafiq-ud-din, the deputy dircctor of E.P.I., also provided valuable assistance with the vaccines.

Astrid Maack and Bernard Benedetti, members of the "first team" that didn't get in spent long frustrating months working and waiting in Pakistan, finally having to return to Europe without the satisfaction of making it into nfghanistan. Their efforts contributed to the final success of this mission, although they were not able to profit from it themselves.

The attempts of Massoud Khalili of Jamiat, and Qaribul Saeed of Hezbi Islami to help organize our entrance are also appreciated. 
Many thanks to Laurance Laumonier for her concern, careful questions and shrewd advice. to Michael Barry for his "letter of transit". to Anke and Rolf Lerch for all the help they gave and their companionship. Thanks to the "Maison Blanche", especially Edouard, Domitille, Yavier and Christian for their friendship, many errands, dinners and coffees. Thanks to Rosanne Klass for her advice, and to cleo Paturis for her enthusiastic support. Thanks also to the Friesen family for their unflagglng interest in helping the Nuristanis, and their many kindnesses to me.

I am grateful to the staff of UNICEF in Pakistan, especially Carl Schönmeyr and Dan O'Dell for their support of this program, and their continuing efforts to foster maternal and child health care in Afghanistan.

Rupert Neudeck of the GED provided a much needed security net with his pledge to provide back-up funding if needed. This allowed us to expand the campaign once inside of Afghanistan. His patience and moral support were also much valued.

I am especially grateful to the donor groups for their willingness to give aid in an unconventional way, to a private individual who for technical reasons could not sign a contract with any single organization. In addition. their continued support through the long difficult months of trying and waiting and not knowing whether we would make it in, and their willingness to send in another team. was enormous.

Mohammad $A L i$ and Abdul khaliq, our local team members, were much more than mere employees. It was only through their constant prolonged untiring efforts that we were ever able to accomplish our entrance into Afghanistan. They stuck with us, protected and defended us in times of danger, and saw the mission through, with all its difficulties, with all their desires to quit, until they had seen us safely back to Pakistan. Many thanks to the friends in Chitral, our staging area. To Freedom Medicine where we stored our supplies and vaccines, and to Agnes mallet who looked after them. Io Haider $\Lambda l$ Shaw and Abbas of the lovely chitral Mountain Inn. who fed-us, hid 
us. and transported us, and raced around chil.ral on many occa-

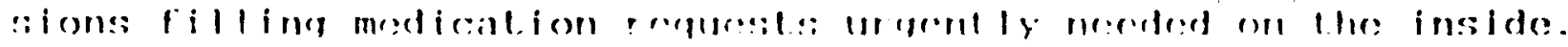
Wy family and husband provided constint encouragement and support. even though this mission also meant hardship for them.

And finally, last but most important of all, are Maria Altstidl and Christoph Bernoulli. the cerman murse and swiss doctor who completed the leam. A betler team could hardly have existed. Thank you friends. 


\section{THE DONURS}

This medical and vaccination program for Nuristan was made possible due to the generous donations of private individuals and several professional and private voluntary organizations. Contributions were made in persomel and maleriel as well as in cash. Actual monelary values are given only when a donation of liquid was made. The total estimated cost of this project was $\$ 90.000-100.000$ (U.S.). Donor organizations are 1 isted al phabetically.

AFGHANISTAN REL.IEF COMITTEE (N.Y..N.Y.) Donation of $\$ 5000$. $\$ 1000$ was applied towards the purchase of vaccines, and $\$ 4000$ was used as salary for Dr. Cita ( $\$ 1000$ !month $\times 4$ mos.).

GERMAN EMERGENCY DOCTORS (Cap Anamur--Cologne, G.F.R.)

1.) Two team members, their transportation, salaries and 1 iving expenses in Pakistan.

2.) The majority of the cold chain and vaccination equipment.

3.) Unrestricted back-up funding which allowed the unanti cipated expansion of the vaceination program unce inside of Afghanistan. Eventual support came to $1 / 3$ to $1 / 2$ of the total costs inside the country.

MEDECINS DU MONDE (Paris)

1.) Two team members, their transportation, salaries, and living expenses in lakistan.

2.) 110,000 rupees cash donation in Pakistan.

3.) Additional funding of 20.000-30.000 rupees dispensed by another team member in entrance attempts.

4.) Purchase of additional cold chain equipment.

5.) Medical insurance. and the use of the MIJM truck and telephone for work related purposes. 
SANTE SUD (Marsel11e) \$b000 towards the purchase of vacelnes.

SWEDISH COMMITTEE FOR AFGHANISTAN (Stockholm)

1.) 175.000 rupees cash donation in Pakistan.

2.) $450 \mathrm{~kg}$. donation of medicines and supplies.

3.) Donation of medicines for the first Nuristan trip.

4.) Use of of fice equipment and administrative support.

UNICEF--Pakistan

$\$ 5000$ dispensed as 5 montins salary to Dr. Cita. (Total time expended on this project exceeded 13 months.)

In addition, a very generous private donor who wished to remain unnamed contributed $\$ 10.000$. without stipulations, at the beginning of the program which provided the necessary early backing to get it of $f$ the ground.

Although he also wished to remained unnamed, another important backer was my husband, who made the first trip to Nuristan possible, and who provided in addition uncounted financial and material support during the second mission. 


\section{DISBURSEIIENT UF CASH DONAIED}

The following 25 pages is a detailed $1 \mathrm{ist}^{\mathrm{t}}$ of the expenditure of liquid contributed for the project. The first page contains a coded chart for those who arc intcrested in categories of expenditure. Receipls and phulucopies of the original records can be had on request.

The overall totals are as follows:

DONATION

$\$ 10,000$

285.000 rupees

\section{DISBURSEMENT}

\author{
$\$ 10.603$ (Spent in \\ U.S. \& Europe prior \\ to departure) \\ 284.300 rspent in \\ lokistan \& Afghanistan)
}

\$500-600 (Projected closing costs: documentation \& rost of bringing remaining medical supplies out of nighanistan) 